\title{
Evaluation of single bed and multi bed dried copra on the quality of extracted coconut oil
}

\author{
H.P.K. Udana* and A.D.U.S. Amarasinghe \\ Department of Chemical and Process Engineering, Faculty of Engineering, University of Moratuwa, Katubedda, Moratuwa.
}

\begin{abstract}
Single bed and multi bed drying of copra was evaluated using a hybrid dryer with three compartments. A high percentage $(>75 \%)$ of white copra resulted in single bed drying at low temperatures $\left(<60{ }^{\circ} \mathrm{C}\right)$, while a comparatively lower percentage $(<22 \%)$ of white copra resulted from multi bed drying. The percentages of white and light brown copra in the bottom, middle and top beds of the multi bed dryer were $85.0 \%, 93.8 \%$ and $91.3 \%$, respectively. A high production rate per unit cross sectional area of $2.06 \mathrm{~kg} / \mathrm{h}$ could be achieved with multi bed drying as compared to single bed drying $\left(0.90 \mathrm{~kg} / \mathrm{h}\right.$ at $55^{\circ} \mathrm{C}$ and $0.97 \mathrm{~kg} / \mathrm{h}$ at $\left.60^{\circ} \mathrm{C}\right)$. The specific moisture extraction in multi bed drying was $0.112 \mathrm{~kg} / \mathrm{kWh}$ as compared to $0.064 \mathrm{~kg} / \mathrm{kWh}$ at $55^{\circ} \mathrm{C}$ and $0.065 \mathrm{~kg} / \mathrm{kWh}$ at $60{ }^{\circ} \mathrm{C}$ in single bed drying. The oil extracted from both white and light brown copra was comparable with the Sri Lanka Standards for virgin coconut oil except the notably higher content of free fatty acids (FFA).
\end{abstract}

Keywords: Coconut oil, copra, hybrid dryer, multi bed drying.

\section{INTRODUCTION}

From ancient times coconut oil has been commonly used as an edible oil in tropical countries. It is mainly used in the food industry and in many non-food applications such as in the production of pharmaceuticals and cosmetics (Sashya et al., 2012). The oil can be extracted from either wet or dry coconut kernels and these extraction processes are named dry or wet processes accordingly. Dry processing with mechanical expellers is the most widely used method of extracting oil in many countries (Canapi et al., 2005; Krishna et al., 2010). In the dry process, the quality of coconut oil is affected by the quality of copra, which is mainly dependent on the method of drying; hot air drying, sun drying or kiln drying. The moisture content of copra needs to be reduced to around $7 \%$ to make good quality copra (Mohanraj \& Chandrasekar, 2008a). A high moisture content increases the free fatty acid (FFA) content, decreases oil recovery and causes rancidity in oil. Contamination by aflatoxin is also possible with the high moisture content in copra (Rodrigo et al., 1996; Marinaa et al., 2009).

Direct contact of copra with smoke and burnt gases in the kiln drying process causes the deposition of polycyclic aromatic hydrocarbons (PAH) on the kernel of the copra (Rodrigo et al., 1996; Wijeratne et al., 1996). Aflatoxin and PAH in copra can be transferred to coconut oil during the extraction process (Guarte et al., 1996). The colour of coconut oil is strongly affected by the colour of copra. The copra becomes brown due to direct contact with smoke during kiln drying and brown copra gives brown coconut oil. In Sri Lanka, the majority of copra is produced by kiln drying and the quality of copra varies with the skill of the operator and with climatic conditions (Rodrigo et al., 1996). Indirect hot air drying is a better alternative to kiln drying. It can produce good quality copra since it prevents smoke deposition and the colour of copra is mostly white or light brown (Satter, 2003; Thanaraj et al., 2007; Mohanraj \& Chandrasekar, 2008b).

Although high temperatures increase the rate of drying, they result in brown copra and also causes case hardening of copra. Case hardening is the formation of a hard outer layer on the coconut kernel, which restricts the passage of moisture from the interior to the surface (Guarte et al., 1996). The maximum temperature for drying copra without quality deterioration was found to be in the range of $60-70{ }^{\circ} \mathrm{C}$. Thanaraj et al. (2004) suggested an optimum temperature of $60{ }^{\circ} \mathrm{C}$, while Mohanraj and Chandrasekar (2008a) reported a maximum drying temperature of $63{ }^{\circ} \mathrm{C}$. Although relative

*Corresponding author (kasunhp@gmail.com) 
humidity and velocity of air also affect the drying rate of copra, the effect is not as considerable as the effect of temperature (Satter, 2001). An air velocity of $0.5 \mathrm{~ms}^{-1}$ has been recommended by Guarte et al. (1996) for industrial scale copra drying while Mohanraj and Chandrasekar (2008a) reported an optimum velocity of $1.2 \mathrm{~ms}^{-1}$.

Multi bed drying is a preferred option as a postharvest treatment due to the high recovery of heat energy from hot air. However, maintaining a uniform temperature gradient and drying conditions within the drying chamber is always a challenge. The objective of the present study was to compare single bed drying with multi bed drying of copra, and evaluate the quality of copra and coconut oil under different drying conditions.

\section{METHODOLOGY}

\section{Hybrid dryer}

A pilot scale hybrid dryer consisting of a solar collector, a biomass stove-heat exchanger unit and a drying chamber was used for the drying experiments (Figure 1). The drying chamber and the heat exchanger were connected through a one (01) horsepower centrifugal blower to provide the necessary air flow to the drying chamber. Air was initially heated in the solar collector before it was passed through the stove-heat exchanger unit. The hot air temperature was controlled with an accuracy of \pm $5^{\circ} \mathrm{C}$ by incorporating a bypass line to supply ambient air in between the drying chamber and the heat exchanger. Further, a gate valve was fixed at the outlet of the heat exchanger to regulate the air flow rate through the dryer.

\section{Drying chamber}

A vertical drying chamber $(600 \times 600 \times 1350 \mathrm{~mm})$ was used to store copra in three compartments as shown in Figure 1. Hot air was allowed to pass from the bottom compartment to the top compartment. The chamber was designed to store around 360 dehusked coconut halves, equally distributed. Drying trays were made out of $25.4 \times$ $25.4 \mathrm{~mm}$ iron mesh. Each compartment was provided with a separate door for loading and unloading of materials. A trapezoidal plenum chamber was fixed below the first drying compartment to maintain proper distribution of inlet air. The outlet of the drying chamber was also fitted with a trapezoidal chamber to guide exhaust air out to the exterior. The outer box of the chamber was made of $1 \mathrm{~mm}$ thick iron sheets and lined with $25 \mathrm{~mm}$ glass wool. The supporting frame was made with L-iron (38.1 $\times 38.1 \mathrm{~mm}$ ). Hollow aluminium tubes of diameter $10 \mathrm{~mm}$ were inserted through the walls of the chamber to insert temperature probes to measure the temperature in each compartment.

\section{Experimental procedure}

\section{Single bed drying}

Single bed drying was performed at two different drying temperatures to determine the drying characteristics of copra. In each experiment, exactly 120 dehusked coconut halves of fully matured coconuts were loaded into the lower compartment of the drying chamber. After $24-26$ hrs of continuous heating, the copra was allowed to cool for $4 \mathrm{hrs}$ in order to avoid case hardening, which

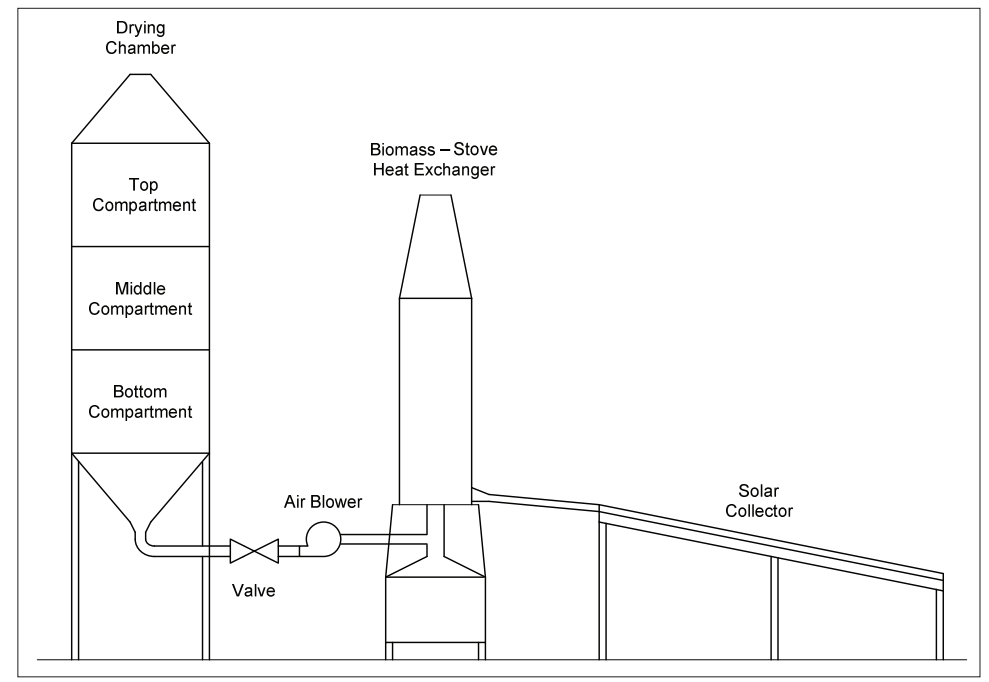

Figure 1: A sketch of solar-biomass hybrid dryer 
may have happened during continuous heating. This period of cooling is shown as a discontinuity in Figures 2 and 3. The kernals were scooped out of the shells and drying was continued further without the shells until a constant weight was recorded. Mean bed temperatures of $55^{\circ} \mathrm{C}$ and $60{ }^{\circ} \mathrm{C}$ were used for the two different trials of the single bed drying by maintaining the heat exchanger outlet temperature in the range of $55-60^{\circ} \mathrm{C}$ and $60-$ $65^{\circ} \mathrm{C}$, respectively.

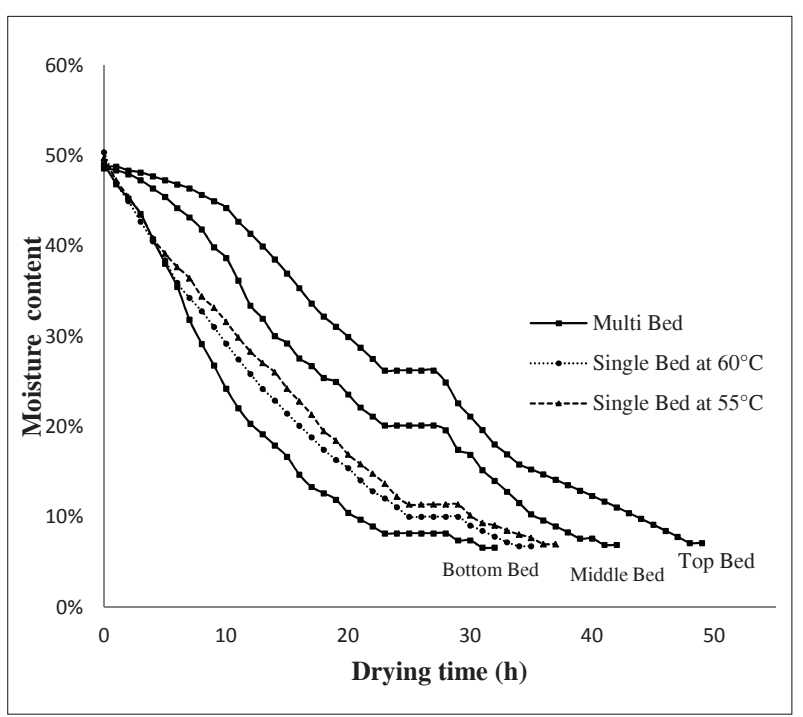

Figure 2: Variation of moisture content with time

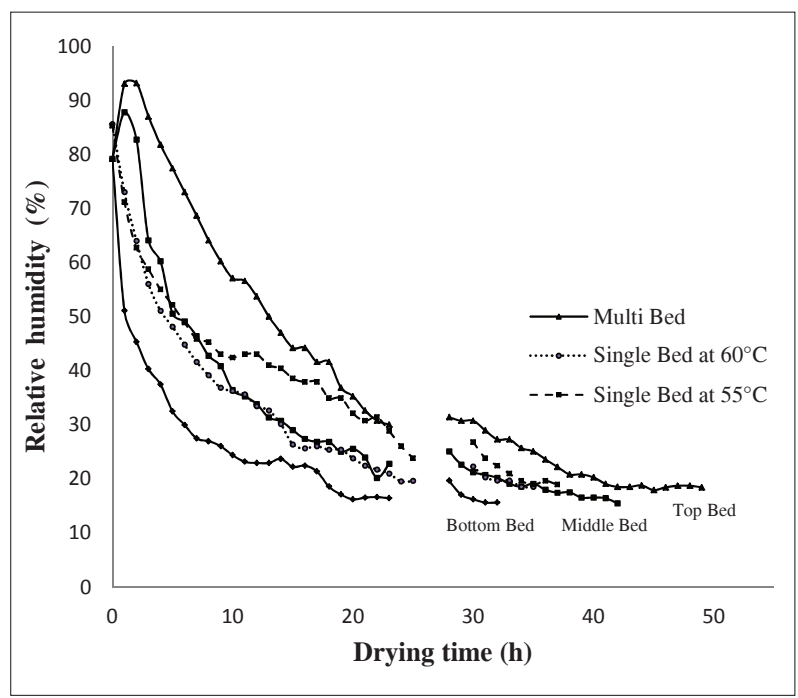

Figure 3: Variation of relative humidity with time

\section{Multi bed drying}

Each compartment of the drying chamber was loaded with 120 dehusked coconut halves. The temperature of the top bed was maintained around $50-60{ }^{\circ} \mathrm{C}$ during drying. Accordingly, the heat exchanger outlet temperature was maintained around $80-90^{\circ} \mathrm{C}$ in the initial drying stages and around $70^{\circ} \mathrm{C}$ in the latter stages. The heating process was stopped for $4 \mathrm{hrs}$ after $23 \mathrm{hrs}$ of drying to avoid case hardening of the copra. This period of cooling is shown as a discontinuity in Figures 2 and 3. The kernels were scooped out from the shells during the cooling period. When the copra in the first compartment reached the preferred moisture content, they were unloaded and the drying process was continued with copra in the other two compartments. Similarly, the copra in the second compartment was unloaded when the desired moisture content was achieved, while keeping the copra in the third compartment for further drying.

\section{Data analysis}

\section{Initial moisture content}

$M_{i}=\left(\frac{W_{0}-W_{f}}{W_{0}}\right) \times 100$

$M_{i}=$ Moisture content on wet basis

$w_{0}=$ Initial weight of the sample

$w_{f}=$ Final weight of the sample

\section{Instantaneous moisture content}

$M_{t}=\frac{m_{i} M_{i^{-}}\left(m_{i}-m_{t}\right)}{m_{t}}$

$m_{t}=$ Mass of material at any given time

$m_{i}=$ Initial mass of material

$M_{t}=$ Moisture content of material at given time

$M_{i}=$ Moisture content on wet basis

\section{Mean bed temperature}

The bed temperature at a given instant is defined as the average of the inlet and outlet air temperatures of the bed. The mean bed temperature was calculated by averaging bed temperatures throughout the entire drying time, neglecting the first $5 \mathrm{hrs}$ of unsteady state operation. 


\section{Specific moisture extraction rate (SMER)}

Specific moisture extraction rate (SMER) is the amount of water evaporated per unit of energy

$S M E R=\frac{m_{l}}{P_{b l}+W \times C}$

$m_{l}=$ Amount of water evaporated during the drying process

$P_{b l}=$ Amount of energy consumed by the blower

$W=$ Amount of biomass fuel used

$C=$ Calorific value of the particular biomass

\section{Grading of copra}

The quality of copra was graded by mainly considering the colour, oil content and the presence of low grade copra. Low grade copra includes scorched copra, slimy copra and mouldy copra.

\section{Analysis of oil content and physicochemical properties}

\section{Oil extraction}

Oil was extracted using an industrial-scale mini expeller. Five-kilogram samples were randomly selected from each grade of copra for extracting oil. The copra was cut into small pieces of about $1-2 \mathrm{~cm}$ using a crusher and heated up to $60{ }^{\circ} \mathrm{C}$ before being fed to the expeller.

\section{Oil content}

A Soxhelt extractor was used to determine the oil content of each copra sample. Scraped copra samples of $10 \mathrm{~g}$ from each grade of copra were used in the Soxhlet unit where $300 \mathrm{~mL}$ of hexane was used as the solvent.

\section{Physicochemical properties of oil}

The free fatty acid (FFA) content, iodine value, saponification value, refractive index, relative density, colour and moisture content of coconut oil samples were tested.

Table 1: Comparison of the results of single bed and multi bed drying of copra

\begin{tabular}{lcccccc}
\hline Experiment & $\begin{array}{c}\text { Mean bed } \\
\text { temperature } \\
\left({ }^{\circ} \mathrm{C}\right)\end{array}$ & $\begin{array}{c}\text { Drying } \\
\text { time } \\
\text { (hours })\end{array}$ & $\begin{array}{c}\text { Moisture } \\
\text { content } \\
(\% \text { wet basis })\end{array}$ & & $\begin{array}{c}\text { Production } \\
\text { of copra } \\
(\mathrm{kg})\end{array}$ & $\begin{array}{c}\text { Rate of } \\
\text { production } \\
\text { of copra } \\
\left(\mathrm{kg} / \mathrm{h} \mathrm{m}^{2}\right)\end{array}$ \\
\hline Single bed at $55^{\circ} \mathrm{C}$ & 55 & 37 & 49.81 & 7.00 & 12.06 & 0.90 \\
Single bed at $60^{\circ} \mathrm{C}$ & 60 & 35 & 50.41 & 6.75 & 12.24 & 0.97 \\
Multi bed - bottom & 73 & 32 & 49.13 & 6.60 & 11.94 & \\
Multi bed - middle & 66 & 42 & 48.62 & 6.91 & 12.11 & $2.06^{\text {a }}$ \\
Multi bed - top & 59 & 49 & 48.82 & 7.11 & 12.37 & \\
\hline
\end{tabular}

${ }^{a}$ Rate of production for multi bed dryer

\section{RESULTS AND DISCUSSION}

\section{Comparison of single bed and multi bed drying}

The results indicate that the final moisture contents of copra from both single bed and multi bed drying were about $7 \%$ (wet basis) (Table 1). In multi bed drying, the moisture that evaporated from the bottom bed passes through the middle and top beds and notably affects the performance. As a result, the drying time and the final moisture content were significantly high in the top bed (49 hours and $7.11 \%$ ) and the middle bed (42 hours and $6.91 \%)$ as compared to the bottom bed (32 hours and $6.60 \%$ ). This effect of moisture migration from the bottom to the top bed is depicted in Figures 2 and 3 . The initial high rate of drying (Figure 2) in the bottom bed of the multi bed dryer and in the single bed dryer is attributed to the removal of surface moisture. Figure 3 depicts that the relative humidity of hot air at the middle and top beds is notably higher than that of the bottom bed during the first 10 hours of drying. This result suggests an alternative option for loading copra into the multi bed dryer, which is to initially load only the bottom bed, loading the middle bed after 5 hours and loading the top bed after 10 hours. 
Table 1 indicates that the drying time of the top bed during multi bed drying operating at $59{ }^{\circ} \mathrm{C}$ was significantly high as compared to single bed drying operating at a relatively low temperature of $55{ }^{\circ} \mathrm{C}$. A similar comparison can be made for the drying times of the middle bed operating at $66{ }^{\circ} \mathrm{C}$ and the single bed operating at a relatively low temperature of $60{ }^{\circ} \mathrm{C}$. This is mainly attributed to moisture migration from the bottom beds to the top beds in multi bed drying. As a result, the relative humidity of air increases considerably (Figure 3) and the moisture extraction rate decreases at the top beds.

A high production rate per unit cross sectional area of $2.06 \mathrm{~kg} / \mathrm{h}$ could be achieved for multi bed drying compared to single bed drying $\left(0.90 \mathrm{~kg} / \mathrm{h}\right.$ at $55{ }^{\circ} \mathrm{C}$ and $0.97 \mathrm{~kg} / \mathrm{h}$ at $60^{\circ} \mathrm{C}$ ). Specific moisture extraction rate (SMER) was found to be $0.112 \mathrm{~kg} / \mathrm{kWh}$ for multi bed drying as compared to $0.064 \mathrm{~kg} / \mathrm{kWh}$ and $0.065 \mathrm{~kg} / \mathrm{kWh}$ for single bed drying at $55{ }^{\circ} \mathrm{C}$ and $60{ }^{\circ} \mathrm{C}$, respectively. The relatively high SMER value for multi bed drying may be attributed to the higher usage of sensible heat of hot air as compared to single bed drying. This is reflected in the high rate of production per unit energy for multi bed drying $(0.0305 \mathrm{~kg} / \mathrm{MJ})$ as compared to that of single bed drying $\left(0.0171 \mathrm{~kg} / \mathrm{MJ}\right.$ and $0.00176 \mathrm{~kg} / \mathrm{MJ}$ at $55{ }^{\circ} \mathrm{C}$ and $60{ }^{\circ} \mathrm{C}$, respectively).

\section{Quality of copra and coconut oil}

Copra produced from hot air drying in both single bed and multi bed drying were free from case hardened, scorched and mouldy copra. Maintaining uniform temperature profiles within the drying chamber of the multi bed dryer was found to be difficult. Therefore, a quality variation among the copra dried in the three different beds was unavoidable. Consequently, three types of copra were obtained and they were categorised according to the colour as white copra, light brown copra and brown copra. Table 2 shows the relative percentages of each type of copra obtained as well as the copra obtained from traditional kiln drying for comparison.

Table 2: Effect of single bed and multi bed drying on the quality of copra

\begin{tabular}{lcccccc}
\hline Experiment & $\begin{array}{c}\text { Mean bed } \\
\text { temperature } \\
\left({ }^{\circ} \mathrm{C}\right)\end{array}$ & $\begin{array}{c}\text { White } \\
\text { copra } \\
(\%)\end{array}$ & $\begin{array}{c}\text { Light } \\
\text { brown } \\
\text { copra }(\%)\end{array}$ & $\begin{array}{c}\text { Brown } \\
\text { copra } \\
(\%)\end{array}$ & $\begin{array}{c}\text { Other } \\
\text { copra } \\
(\%)\end{array}$ & $\begin{array}{c}\text { Oil content } \\
\text { (percentage } \\
\text { by weight })\end{array}$ \\
\hline Single bed at $55^{\circ} \mathrm{C}$ & 55 & 82.00 & 16.40 & 0 & 1.60 & 60.18 \\
Single bed at $60^{\circ} \mathrm{C}$ & 60 & 76.00 & 23.17 & 0 & 0.83 & 60.44 \\
Multi bed - bottom & 73 & 10.32 & 74.68 & 13.33 & 1.67 & 60.33 \\
Multi bed - middle & 66 & 13.33 & 80.46 & 4.16 & 2.15 & 59.25 \\
Multi bed - top & 59 & 42.33 & 49 & 2 & 6.67 & 59.43 \\
Kiln drying & & 0 & 0 & 97.8 & 2.2 & 60.59 \\
\hline
\end{tabular}

The percentages of white copra produced at mean bed temperatures $55{ }^{\circ} \mathrm{C}$ and $60{ }^{\circ} \mathrm{C}$ of single bed drying were $82 \%$ and $76 \%$, respectively. The remaining copra in these two experiments were light brown in colour. Thanaraj et al. (2007) were also able to produce white copra with a percentage slightly above $70 \%$, at a drying temperature around $60^{\circ} \mathrm{C}$ in their research using a solarbiomass hybrid rotary copra dryer.

In multi bed drying, the percentage of white copra found in the bottom, middle and top beds were $10.32 \%$, $13.33 \%$ and $42.33 \%$, respectively. These values are significantly lower than the values for single bed drying. Notably low production of white copra in the bottom bed during multi bed drying may be attributed to significantly high bed temperatures (Figure 4). On the other hand, the mean bed temperature of the top bed in multi bed drying was comparable to that of the mean bed temperature during single bed drying at $55^{\circ} \mathrm{C}$, but the production of white copra was significantly low in the top bed. This may be attributed to the considerably higher drying time (49 hours) in the top bed during multi bed drying than that of single bed drying at a comparable temperature ( 35 hours). This result indicates that high temperature is not the only factor responsible for the change of copra colour to brown, but the time of drying also plays a contributing role. Although the amount of white copra was low, the majority of copra (more than $90 \%$ ) from multi bed drying was light brown or pale yellow in colour. In contrast, more than $97 \%$ of copra produced in conventional kiln drying was found to be dark brown in colour. 


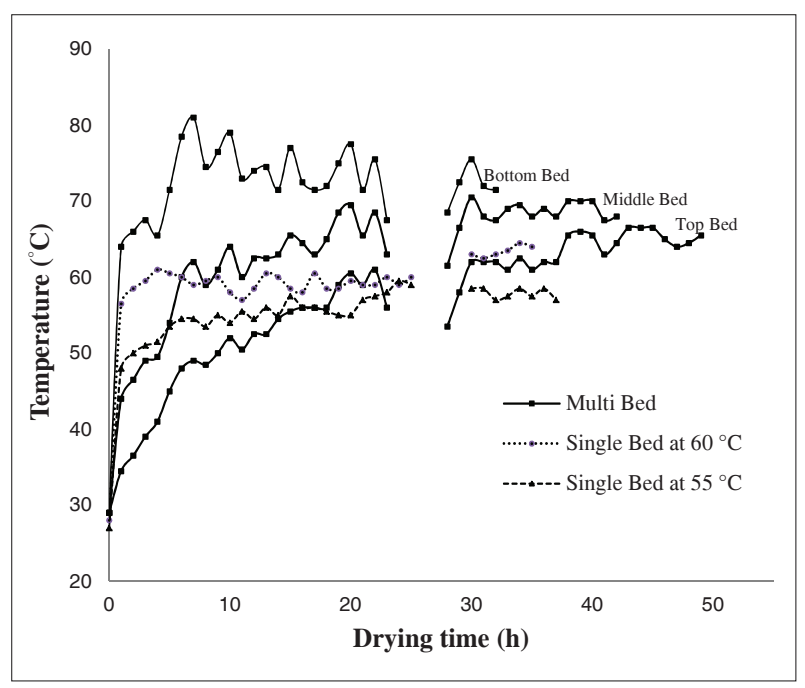

Figure 4: Variation of bed temperature with time
The oil content of copra produced in both single bed and multi bed drying was found to be almost the same with a value around $60 \%$ by mass. Comparison of the physicochemical properties of oil extracted from each type of copra with SLS 313 standards is shown in Table 3. Coconut oil extracted from white and light brown copra was very similar to virgin coconut oil in appearance and in quality except for the content of free fatty acids. Conventionally, virgin coconut oil is extracted using wet coconut without testa (Krishna et al., 2010). In the present study, the oil was mechanically extracted from dry coconut without removing the testa. Removal of testa from the kernel is a labour intensive operation, and hence, this method is advantageous. However, the presence of testa and high temperature during the operation might have increased the FFA content. Further, traditional kiln drying was unable to produce white or light brown copra, while the colour of the extracted oil from kiln dried copra was pale yellow.

Table 3: Comparison of oil quality with SLS standards

\begin{tabular}{|c|c|c|c|c|c|c|}
\hline Characteristic & $\begin{array}{l}\text { Virgin } \\
\text { coconut } \\
\text { oil (SLS) }\end{array}$ & $\begin{array}{c}\text { White } \\
\text { coconut } \\
\text { oil (SLS) }\end{array}$ & $\begin{array}{l}\text { Coconut } \\
\text { oil (SLS) }\end{array}$ & $\begin{array}{l}\text { Oil from } \\
\text { white } \\
\text { copra }\end{array}$ & $\begin{array}{l}\text { Oil from } \\
\text { light brown } \\
\text { copra }\end{array}$ & $\begin{array}{c}\text { Oil from } \\
\text { brown } \\
\text { copra }\end{array}$ \\
\hline $\begin{array}{l}\text { Colour }(25 \mathrm{~mm} \text { cell on } \\
\text { the Lovibond colour scale } \\
\text { expressed in } \mathrm{Y}+5 \mathrm{R})\end{array}$ & 1 & 4 & 5 & 0.8 & 1 & 3.1 \\
\hline Relative density at $30^{\circ} \mathrm{C}$ & $\begin{array}{l}0.915- \\
0.920\end{array}$ & $\begin{array}{l}0.915- \\
0.920\end{array}$ & $\begin{array}{l}0.915- \\
0.920\end{array}$ & 0.919 & 0.919 & 0.918 \\
\hline Refractive index at $40{ }^{\circ} \mathrm{C}$ & $\begin{array}{l}1.4480- \\
1.4492\end{array}$ & $\begin{array}{l}1.4480- \\
1.4492\end{array}$ & $\begin{array}{l}1.4480- \\
1.4492\end{array}$ & 1.4489 & 1.4490 & 1.4490 \\
\hline $\begin{array}{l}\text { Moisture and other matter } \\
\text { volatile at } 105^{\circ} \mathrm{C}, \max .\end{array}$ & 0.5 & 0.4 & 0.4 & 0.34 & 0.37 & 0.38 \\
\hline $\begin{array}{l}\text { Free fatty acids } \\
\text { as lauric acid } \\
\text { percentage by mass }\end{array}$ & 0.2 (max.) & 0.8 (max.) & 0.8 (max.) & 0.71 & 0.63 & 0.68 \\
\hline Iodine value & $6.0-11.0$ & $7.5-11.0$ & $7.5-11.0$ & 8.53 & 7.99 & 8.65 \\
\hline Saponification value & 255 (min) & $248-264$ & $248-264$ & 252 & 255 & 258 \\
\hline
\end{tabular}

\section{CONCLUSION}

The amount of white copra that can be obtained is mainly dependent on the drying temperature. In single bed drying, the production of brown copra could be minimised by maintaining the drying temperature below $70^{\circ} \mathrm{C}$. Low quality copra such as scorched copra was not observed using this process.
The SMER value was considerably higher $(0.112 \mathrm{~kg} / \mathrm{kWh})$ in multi bed drying than in single bed drying $(0.064 \mathrm{~kg} /$ $\mathrm{kWh}$ ) and the rate of production of copra per unit cross sectional area for multi bed drying was $2.06 \mathrm{~kg} / \mathrm{h}$, which is almost double the rate reported in single bed drying $(0.97 \mathrm{~kg} / \mathrm{h})$. The main drawback of multi bed drying is the difficulty in maintaining comparable temperature profiles in the three beds. Therefore, a quality variation 
among the copra dried in the three different beds was unavoidable. More specifically, the production of brown copra was high in the bottom bed where the mean bed temperature was more than $70{ }^{\circ} \mathrm{C}$. Although the production of white copra was comparatively low in multi bed drying, the percentage of white and light brown copra was found to be more than $90 \%$.

Coconut oil, which is very similar to virgin coconut oil in appearance and physicochemical properties (according to SLS standards) could be extracted from both white and light brown copra. Further, this colourless oil was extracted without removing the thick brown skin of the kernel (pairing), the removal of which involves labour. However, the free fatty acid content was significantly higher than the specification for virgin coconut oil ( $0.2 \mathrm{max})$. This may be mostly attributable to the pairing and the heating of copra. Therefore, future research may be focused on improving this process to achieve a low FFA content in the extracted oil. Further, high temperature oil extraction in the presence of metal surfaces may yield polycyclic aromatic hydrocarbons $(\mathrm{PAH})$, and therefore, special care must be given to use water cooling at the point of expulsion from the expeller.

\section{Acknowledgement}

The authors are grateful to the testing facilities and the support given by the staff of the Coconut Development Authority, Sri Lanka.

\section{REFERENCES}

1. Canapi E.C., Agustin Y.T.V., Moro E.A., Pedrosa E. Jr. \& Bendano M.L.J. (2005). Coconut oil. Bailey's Industrial Oil and Fat Products (ed. F. Shahidi), $6^{\text {th }}$ edition, pp. $123-147$. John Wiley and Sons, Inc., New York, USA. DOI: http://dx.doi.org/10.1002/047167849x.bio054

2. Guarte R.C., Mfihlbauer W. \& Kellert M. (1996). Drying characteristics of copra and quality of copra and coconut oil. Postharvest Biology and Technology 9: 361 - 372 .
3. Krishna A.G.G., Raj G., Bhatnagar A.S., Kumar P.K.P. \& Chandrashekar P. (2010). Coconut oil: chemistry, production and its applications - a review. Indian Coconut Journal 73: 15 - 27.

4. Marinaa A.M., Man Y.B.C. \& Amin I. (2009). Virgin coconut oil: emerging functional food oil. Trends in Food Science and Technology 20: 481 - 487.

DOI: http://dx.doi.org/10.1016/j.tifs.2009.06.003

5. Mohanraj M. \& Chandrasekar P. (2008a). Drying of copra in a forced convection solar dryer. Biosystems Engineering 99: $604-607$.

DOI:http://dx.doi.org/10.1016/j.biosystemseng.2007.12.004

6. Mohanraj M. \& Chandrasekar P. (2008b). Comparison of drying characteristics and quality of copra obtained in a forced convection solar dryer and sun drying. Journal of Scientific and Industrial Research 67: 381 - 385.

7. Rodrigo M.C.P., Amarasiriwardene B.L. \& Samarajeewa U. (1996). Some observations on copra drying in Sri Lanka. Cocos 11: $21-31$.

8. Sashya M.M.M., Meedeniya D. \& Coorey R.V. (2012). Quality assessment of commercially available coconut oils in Sri Lanka using refractometry. Proceedings of the Technical Sessions, Institute of Physics - Sri Lanka 28: $37-44$.

9. Satter M.A. (2001). Optimization of copra drying factors by Taguchi method, $4^{\text {th }}$ International Conference on Mechanical Engineering, 26 - 28 December, Dhaka, Bangladesh, pp. III $23-27$.

10. Satter M.A. (2003). Design and development of a portable copra dryer, Proceedings of the International Conference on Mechanical Engineering (ICME2003), 26 - 28 December, Dhaka, Bangladesh.

11. Thanaraj T., Dharmasena N.D.A. \& Samarajeewa U. (2004). Development of a rotary solar hybrid dryer for small scale copra processing. Tropical Agricultural Research 16: $305-315$.

12. Thanaraj T., Dharmasena N.D.A. \& Samarajeewa U. (2007). Comparison of quality and yield of copra processed in CRI improved kiln drying and sun drying. Journal of Food Engineering 78: 1446 - 1451.

DOI: http://dx.doi.org/10.1016/j.jfoodeng.2006.01.016

13. Wijeratne M.C.P., Samarajeewa U. \& Rodrigo M.C.P. (1996). Polyaromatic hydrocarbons in coconut kernel products. Journal of the National Science Council of Sri Lanka 24(4): 285 - 297. 